DOI.

https://doi.org/10.22219/fths.v3i2

Received: April 2020

Accepted: Mei 2020

Available online: Juli 2020

\title{
Pengaruh Pemberian Sari Buah Markisa Ungu (Passiflora edulis Var. Edulis sims) terhadap Ketebalan Dinding Aorta Tikus (Rattus norvegicus Strain Wistar) yang Diberi Diet Aterogenik
}

\author{
Hanif Alamudin Manshur ${ }^{1}$, Hiya Alfi Rahmah2 ${ }^{*}$ \\ ${ }^{1}$ Program Studi Teknologi Pangan, Fakultas Pertanian-Peternakan, Universitas Muhammadiyah \\ Malang, Malang, Indonesia \\ ${ }^{2}$ Program Studi Ilmu Gizi, Fakultas Ilmu-Ilmu Kesehatan, Universitas Jenderal Soedirman, \\ Purwokerto, Indonesia \\ *Corresponding Author email: rahmah.hiyaalfi@gmail.com
}

\begin{abstract}
Coronary heart disease which the main cause of death is a clinical manifestation of atherosclerosis. Atherosclerosis is an accumulation of cholesterol crystals on arteries wall. Purple passion fruit concentrate (Passiflora edulis var. edulis Sims) contains beta carotene, vitamine $C$ and flavonoids compounds. Those are antioxidants that may inhibit atherosclerosis through hypolipidemic and antioxidative effects. The purpose of this study was to determine the effect of purple passion fruit concentrate (Passiflora edulis var.edulis Sims) to the thickness of aortic wall of rats (Rattus norvegicus wistar strain) that had been given atherogenic diet. This research was experimental, with posttest only control group design. The study was conducted for 60 days using 30 male wistar rats divided randomly into 5 groups: $K(-)$ (normal diet), $K(+)$ (atherogenic diet), P1 (atherogenic diet + passion fruit concentrate $17,5 \mathrm{ml} / \mathrm{kg} B \mathrm{~W}$ ), P2 (atherogenic diet + passion fruit concentrate $21,87 \mathrm{ml} / \mathrm{kgBW}$ ), and P3 (atherogenic diet + passion fruit juice $26,25 \mathrm{ml} / \mathrm{kgBW}$ ). The thickness of the aortic wall was measured by an optical microscope completed with ocular micrometer at a magnification of 400 times. Analysis of data using One Way ANOVA followed by Post Hoc Tuckey. The results showed that administration of the purple passion fruit concentrate (Passiflora edulis var. Edulis Sims) could reduce the thickness of aortic wall of rats (Rattus norvegicus wistar strain) which were exposed to atherogenic diet with an optimal dose was $17.5 \mathrm{ml} /$ $\mathrm{kgBW} / \mathrm{day}(\mathrm{p}<0.001)$. Suggestions of this study was to test the effectiveness of the purple passion fruit concentrate when applied to humans.
\end{abstract}

Keywords : aortic wall, atherogenic diet, purple passion fruit concentrate, Passiflora edulis var. edulis Sims,

\section{PENDAHULUAN}

Perkembangan dunia industri dan teknologi di era globalisasi yang tengah melanda negara-negara sedang berkembang sebagai-mana di Indonesia memberikan dampak perbaikan tingkat hidup. Hal ini menjadikan kesehatan masyarakat meningkat, disamping itu terjadi pula perubahan pola hidup. Perubahan pola hidup ini yang menyebabkan pola penyakit dan penyebab kematian berubah. Penyakit-penyakit yang mematikan bukan lagi penyakit 
infeksi dan rawan gizi namun telah bergeser kearah penyakit-penyakit degeneratif, diantaranya adalah penyakit jantung dan pembuluh darah (kardiovaskuler) (Susiana et al., 2006).

Di negara-negara industri, penyakit jantung koroner (PJK) dan stroke merupakan 40-50 \% penyebab kematian (Muchtadi, 2007). Penyakit jantung koroner telah menyebabkan 425.425 kematian pada tahun 2006. Hingga saat ini, 17.600.000 penduduk Amerika, terdiri dari 9.200.000 pria dan 8.400.000 wanita, hidup dengan riwayat myocardial infark dan angina pektoris. Kedua gejala di atas biasa tampak pada penderita PJK (American Heart Assosiation, 2011).

Penyakit jantung koroner menjadi salah satu penyumbang terbesar angka kematian di Indonesia. Penyakit ini menjadi penyebab 26,4\% kematian dan angka tersebut empat kali lebih tinggi dari persentase kematian akibat kanker (6\%) (PERKI, 2019). Pada tahun 2013, prevalensi penyakit jantung koroner berdasarkan hasil diagnosis dokter atau gejala yang timbul pada kelompok umur di atas 15 tahun telah mencapai $1.5 \%$ atau sekitar 3 juta jiwa (BALITBANGKES, 2013). Sementara itu, pembiayaan kesehatan yang dikeluarkan oleh BPJS untuk penanganan penyakit jantung koroner semakin meningkat dari tahun ke tahun. Berturut-turut dari tahun 2014, 2016 dan 2018, BPJS sudah mengeluarkan dana sebesar 4,4 triliun, 7,4 triliun hingga 9,3 triliun rupiah (P2PTM Kemenkes RI, 2019). Beban pembiayaan penanganan penyakit jantung koroner tersebut dapat secara bertahap dikurangi dengan cara mengendalikan faktor resiko.

Faktor resiko dari penyakit jantung koroner terbagi menjadi dua, yaitu faktor resiko yang tidak dapat dimodifikasi dan yang dapat dimodifikasi. Faktor resiko yang tidak dapat dirubah meliputi usia, jenis kelamin, dan keturunan / ras. Sementara itu, faktor resiko yang dapat dimodifikasi antara lain, merokok, dislipidemia, hipertensi, diabetes melitus, kurang aktivitas fisik, kegemukan, diet yang tidak sehat, stres serta konsumsi alkohol berlebih. (Triyanto, 2009).

Sehubungan dengan faktor resiko penyakit jantung koroner, yaitu diet yang tidak sehat, seiring meningkatnya kesejahteraan hidup penduduk suatu negara, maka konsumsi akan produk pangan hewani akan meningkat. Produk pangan hewani yang berasal ternak cenderung memiliki kadar asam lemak jenuh yang tinggi. Konsumsi asam lemak jenuh yang berlebihan beresiko menaikkan kadar kolesterol LDL (low density lipoprotein) dalam darah (Triyanto, 2009). Kolesterol LDL mudah menempel di dinding pembuluh darah. Molekul LDL dapat melekat di dinding pembuluh darah karena adanya proses oksidasi oleh radikal bebas. LDL yang teroksidasi tersebut memodifikasi makrofag menjadi foam cell sehingga akan membentuk gumpalan (plaque) yang makin lama semakin membesar, dan hasil akhirnya berupa penyempitan pembuluh darah. 
Terbentuknya sel busa inilah yang kemudian mengawali pembentukan aterosklerosis. Aterosklerosis adalah gejala klinis penimbunan kolesterol pada lapisan dalam dinding pembuluh darah, yang dapat mengawali timbulnya penyakit jantung koroner. (Sandjaja et al., 2009).

Solusi yang tepat untuk menangani peningkatan kolesterol total, kolesterol LDL, kenaikan kadar trigliserida serta penurunan kadar HDL adalah dengan upaya nonfarmakologik yang meliputi modifikasi diet, latihan jasmani serta pengelolaan berat badan. Penanganan melalui efek farmakologik untuk berbagai macam penyembuhan rata-rata memiliki efek samping negatif (Anwar, 2004). Pencegahan aterosklerosis lebih baik apabila ditemukan cara untuk mengurangi resiko terbentuknya sel busa (foam cell) dengan menggunakan bahan-bahan alami oleh karena bahan yang berasal dari alam terbukti secara ilmiah memberikan manfaat dalam pencegahan atau pengobatan penyakit yang pada umumnya tidak menyebabkan efek samping negatif dan aman digunakan untuk manusia (Dalimarta, 2000).

Markisa ungu (Passiflora edulis var. edulis Sims) adalah buah yang memiliki nilai gizi tinggi, salah satunya adalah kandungan senyawa antioksidannya. Sari buah markisa ungu banyak mengandung vitamin A, vitamin $\mathrm{C}$, beta karoten, dan senyawa flavonoid. Beta karoten dalam markisa ungu mempunyai efek antioksidan kuat yang dapat mencegah oksidasi LDL sehingga mampu mengurangi resiko terbentuknya aterosklerosis (Whiting, 2004). Vitamin C mencegah modifikasi LDL dengan cara menetralkan radikal bebas di lingkungan berair (aqueous milieu) (Carr et al.,2000). Flavonoid dapat mencegah oksidasi LDL serta mempunyai efek anti-inflamasi, penurun kolesterol, antihipertensi dan aktivitas antiplatelet. Selain itu, komponen ini mampu menghambat migrasi dan proliferasi sel otot polos serta meningkatkan fungsi pembuluh darah. (Gross, 2004).

Penelitian ini dilakukan untuk menguji efektivitas sari buah markisa ungu dalam menurunkan ketebalan dinding aorta tikus Wistar jantan yang diberi diet aterogenik.

\section{METODE PENELITIAN}

\section{Bahan}

Buah markisa ungu didapatkan dari salah satu kebun rumah tangga di daerah Lowokwaru Kota Malang. Untuk ransum tikus, terdiri dari diet normal dan diet aterogenik. Diet normal terdiri dari campuran comfeed PARS dan tepung terigu. Diet aterogenik terdiri dari campuran comfeed PARS, tepung terigu, kuning telur bebek, lemak kambing, minyak kelapa, minyak babi dan asam kolat. 
Alat

Alat yang digunakan terdiri dari alat pemeliharaan hewan coba (kandang dari kotak plastik, tutup kandang dari anyaman kawat, botol air), alat pembuat ransum hewan coba (baskom plastik, timbangan, sarung tangan, gelas ukur), alat pengambilan sampel (seperangkat alat bedah, kapas dan plastic bening), alat pembuatan sari buah markisa (pisau, talenan, sendok, baskom, blender, kain saring dan botol), alat pemberian sari buah markisa kepada hewan coba (sonde lambung), alat untuk pembuatan sediaan histologi (kaca objek, kaca penutup, staining jar, mikrotom, inkubator, gelas beker, blok parafin) dan alat untuk mengukur penebalan dinding intima media pembuluh darah aorta (mikrometer, mikroskop cahaya)

\section{Pembuatan Sari Buah Markisa}

Sari buah markisa ungu diberikan per oral dengan sonde setiap hari sekali. Sari buah dibuat dengan cara memblender bagian buah yang dapat dimakan (edible portion), kemudian menyaring hasil blenderannya dengan kain saring halus. Buah markisa ungu diperoleh dari daerah Kecamatan Lowokwaru Kota Malang.

\section{Penyiapan Hewan Coba}

Sampel penelitian sebanyak 30 tikus putih Rattus Novergicus Strain Wistar jantan, umur \pm 2 bulan, sehat, dengan berat badan 150-200 gram. Baik diet normal maupun diet aterogenik, diberikan sebanyak $40 \mathrm{~g}$ per tikus per hari. Tikus dibagi secara acak menjadi 5 kelompok dan diberi perlakuan selama 60 hari sebagai berikut:

1. Kelompok kontrol negatif $(K(-))$ yang diberikan diet normal tanpa sari buah markisa.

2. Kelompok kontrol positif $(\mathrm{K}(+))$, yang diberikan diet aterogenik tanpa sari buah markisa, namun mendapat perlakuan sonde air sebagai placebo.

3. Kelompok perlakuan 1 (P1), yang diberikan diet aterogenik + sari buah markisa $17,5 \mathrm{ml} / \mathrm{kgBB}$.

4. Kelompok perlakuan 2 (P2), yang diberikan diet aterogenik + sari buah markisa $21,87 \mathrm{ml} / \mathrm{kgBB}$.

5. Kelompok perlakuan 3 (P3), yang diberikan diet aterogenik + sari buah markisa $26,25 \mathrm{ml} / \mathrm{kgBB}$.

\section{Uji Ketebalan Dinding Aorta Tikus}

Variabel tergantung adalah ketebalan dinding aorta. Ketebalan dinding aorta adalah ketebalan dinding aorta abdominalis dari tunika intima sampai dengan tunika adventisia, dengan satuan ukuran mikron. Pengukuran ketebalan 
dinding aorta dilakukan di delapan zona pandang dengan bantuan mikroskop yang dilengkapi dengan mikrometer okuler pada pembesaran 400 kali.

\section{Rancangan Percobaan dan Analisa Data}

Penelitian ini merupakan penelitian eksperimental. Rancangan eksperimental yang digunakan adalah posttest only control group design. Untuk mengetahui perbedaan dari masing-masing perlakuan digunakan uji statistik One way Anova, dilanjutkan dengan uji Post Hoc Tukey dengan nilai $\mathrm{p} \leq 0,05$.

\section{HASIL DAN PEMBAHASAN}

\section{Tingkat Asupan Ransum Tikus Selama Fase Perlakuan}

Tingkat asupan ransum merupakan banyaknya ransum dalam berat kering yang dikonsumsi oleh tikus dibandingkan dengan kebutuhan yang dinyatakan dalam persentase. Kebutuhan ransum tikus sehari dalam berat kering adalah sebesar 40 gram. Analisis terhadap asupan ransum harian tikus yang dilakukan menggunakan uji One Way ANOVA menunjukkan bahwa ada perbedaan tingkat asupan ransum yang signifikan pada kelima kelompok perlakuan dengan nilai $\mathrm{p}$ $=0,013(\alpha=0,05)$. Analisis dilanjutkan dengan menggunakan uji Post Hoc Tuckey untuk mengetahui pada kelompok perlakuan mana perbedaan bermakna tersebut terjadi. Tingkat asupan ransum sehari selama fase perlakuan dapat dilihat pada gambar 1 .

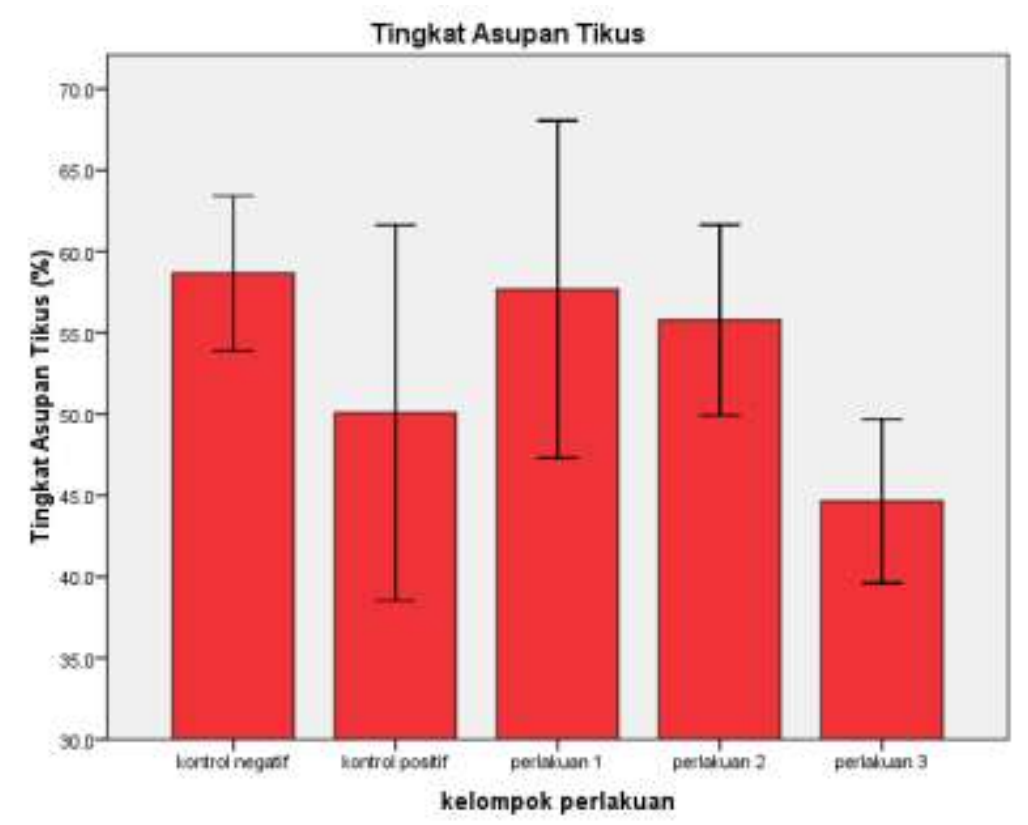

Gambar 1. Rata-rata Tingkat Asupan Ransum Tikus per Hari (gram) Selama Fase Perlakuan. 
Pada penelitian ini, tingkat asupan ransum pada kelompok $\mathrm{K}(-)$ dan $\mathrm{P} 1$ berbeda signifikan terhadap kelompok P3. Sementara tingkat asupan ransum pada kelompok $\mathrm{K}(+)$ dan $\mathrm{P} 2$ tidak berbeda secara signifikan terhadap kelompok lainnya.

Selama tujuh hari masa adaptasi, tikus percobaan mendapatkan diet normal sebanyak 40 gram per hari dengan komposisi comfeed PARS, tepung terigu, dan air. Setelah masa adaptasi berakhir, semua kelompok perlakuan, kecuali kontrol negatif, dilanjutkan dengan pemberian diet aterogenik yang terdiri dari comfeed $P A R S$, tepung terigu, kolesterol, minyak babi, dan air selama 60 hari sedangkan kelompok kontrol negatif diberikan diet normal hingga akhir masa penelitian (60 hari). Selama 60 hari tersebut, kelompok perlakuan P1, P2, dan P3 mendapat sonde sari buah markisa sesuai dosis masing-masing kelompok.

Berdasarkan hasil penelitian, tingkat asupan ransum tikus antar kelompok perlakuan berbeda jumlahnya. Tingkat asupan ransum paling tinggi ditemukan pada kelompok $\mathrm{K}(-)$ sedangkan yang paling rendah ditemukan pada kelompok P3. Ada beberapa faktor yang mempengaruhi tingkat asupan ransum, energi, dan zat gizi pada tikus wistar, antara lain keadaan fisiologis tikus, misalnya tikus stres karena diberikan perlakuan sonde sehingga mempengaruhi nafsu makannya, bentuk pakan, tekstur, dan keadaan kandang juga dapat mempengaruhi nafsu makan pada tikus.

Tingkat asupan ransum pada kelompok $\mathrm{K}(-)$ dan $\mathrm{P} 1$ berbeda secara signifikan terhadap kelompok P3. Sementara tingkat asupan ransum pada kelompok K(+) dan P2 tidak berbeda signifikan terhadap kelompok lainnya. Dari sini, dapat diketahui bahwa perbedaan jenis ransum tidak terlalu berpengaruh terhadap tingkat asupan ransum tikus. Hal tersebut dibuktikan dengan tidak adanya perbedaan tingkat asupan ransum yang signifikan antara kelompok $\mathrm{K}(-)$ yang mendapat diet normal dengan $\mathrm{K}(+)$ yang mendapat diet aterogenik. Namun kelompok $\mathrm{K}(-)$ yang mendapat diet normal tetap mempunyai tingkat asupan ransum yang lebih tinggi dibandingkan dengan kelompok perlakuan yang memperoleh diet aterogenik. Hal ini terjadi karena pada bentuk ransum diet normal, teksturnya lebih kasar sesuai dengan ransum tikus sehari-hari dan berdasarkan pengamatan dari segi organoleptik, aroma yang ditimbulkan dari diet aterogenik lebih tengik jika dibandingkan dengan diet normal. Ketengikan pada ransum aterogenik dikarenakan adanya penambahan minyak babi dan kolesterol dimana pada minyak babi banyak mengandung asam lemak tak jenuh (Baedori, 2008). Molekul-molekul lemak yang mengandung radikal asam lemak tak jenuh mudah mengalami oksidasi dan menjadi tengik. Bau tengik yang tidak sedap tersebut disebabkan oleh pembentukan senyawa-senyawa hasil pemecahan hidroperoksida (Winarno, 2002). 
Kelompok P3 mempunyai tingkat asupan ransum yang paling rendah diantara kelompok lainnya serta memiliki perbedaan tingkat asupan ransum yang signifikan dengan $\mathrm{K}(-)$ dan P1. Hal itu terjadi karena pada kelompok P3 mendapatkan dosis sari buah markisa yang paling tinggi sehingga harus diberikan sebanyak 2 kali sonde. Dengan pemberian 2 kali sonde ini menyebabkan stres fisiologis yang dialami tikus bertambah bila dibandingkan dengan kelompok yang hanya mendapatkan 1 kali sonde seperti $\mathrm{K}(+), \mathrm{P} 1$, dan P2. Meningkatnya stres fisiologis akan merangsang sekresi CRH (corticotropin releasing hormone) dari hipotalamus. CRH berefek secara langsung untuk menurunkan asupan pakan (Hollopeter et al.,1998). Selain itu, pemberian sari buah markisa dengan dosis tertinggi ini menyebabkan penuhnya volume lambung sehingga tikus cepat merasa kenyang dan berkurang nafsu makannya.

Sehubungan dengan hal di atas, kelompok P1 dan P2 mempunyai tingkat asupan ransum yang lebih banyak daripada $\mathrm{K}(+)$, bahkan tidak berbeda jauh rata-ratanya bila dibandingkan dengan $\mathrm{K}(-)$ yang menerima diet normal. Ini menunjukkan bahwa dalam kondisi frekuensi sonde yang sama (1 kali sonde), kelompok tikus dengan diet aterogenik yang mendapat sonde sari buah markisa (P1 dan P2) mempunyai tingkat asupan ransum yang lebih banyak daripada $\mathrm{K}(+)$ yang hanya mendapat sonde air biasa. Hal tersebut membuktikan bahwa sari buah markisa memiliki efek meningkatkan nafsu makan, walaupun pakan yang sedang diberikan berbeda sifat organoleptiknya bila dibandingkan dengan pakan tikus sehari-hari. Sari buah markisa mengandung alkaloid seperti, passiflorine, yang mempunyai efek sedative (penenang) dan anti anxiety sehingga cocok untuk meredakan stress (Karsinah $d k k ., 2010)$. Oleh karena adanya kedua efek tersebut, buah markisa biasa digunakan untuk mengatasi gejala neurasthenia (kelelahan kronis, lemah, tidak nafsu makan, tidak bisa konsentrasi, dan susah tidur) (Hakimah, 2010).

\section{Asupan Energi Tikus Selama Fase Perlakuan}

Hasil uji One Way ANOVA menunjukkan bahwa ada perbedaan asupan energi yang signifikan pada kelima kelompok perlakuan dengan nilai $\mathrm{p}<0,001$ $(\alpha=0,05)$. Asupan energi selama fase perlakuan dapat dilihat pada gambar 2. 


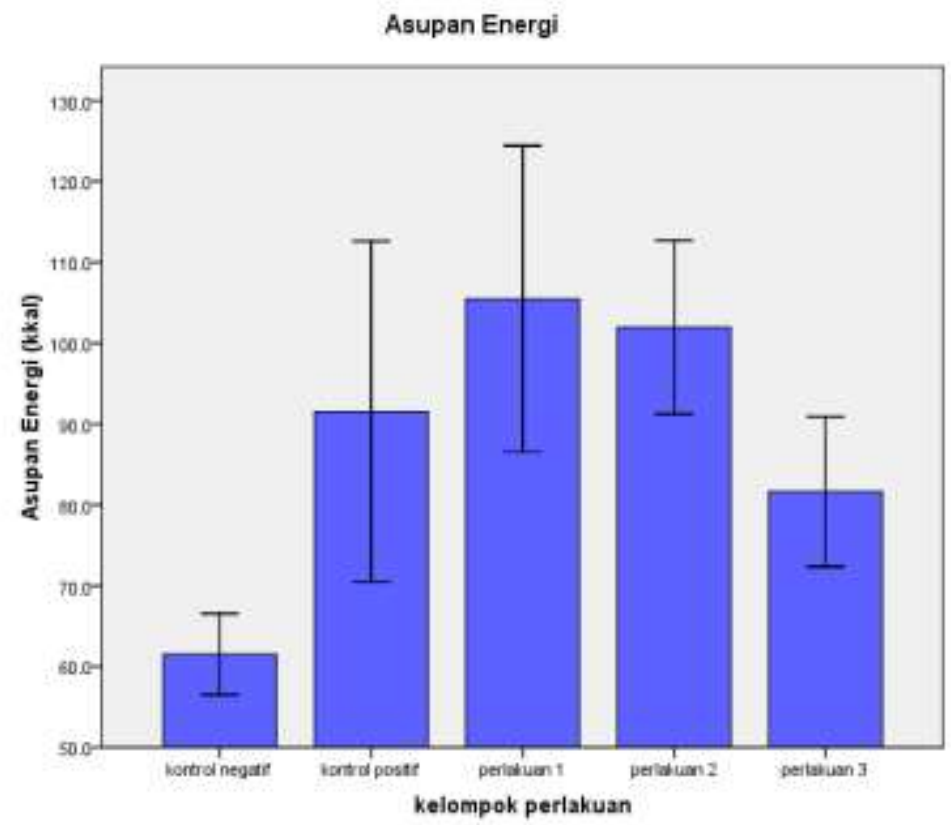

Gambar 2. Asupan energi tikus per hari selama fase perlakuan.

Asupan energi pada kelompok $\mathrm{K}(-)$ berbeda signifikan terhadap kelompok $\mathrm{K}(+)$, P1 dan P2. Asupan energi pada kelompok P3 juga berbeda signifikan hanya terhadap kelompok P1. Diet normal memiliki kepadatan energi yang lebih rendah daripada diet aterogenik. Dalam 40 gram diet normal mengandung energi sebesar $105 \mathrm{kkal}$ sedangkan dalam 40 gram diet aterogenik mengandung energi sebesar 182,76 kkal. Oleh karena itulah, kelompok K(-) mempunyai perbedaan asupan energi yang signifikan bila dibandingkan dengan $K(+)$, P1 dan P2. Di satu sisi, walaupun mendapat diet aterogenik, kelompok P3 tidak memiliki perbedaan asupan energi yang signifikan dengan kelompok $\mathrm{K}(-)$ karena tingkat asupan ransumnya yang sangat rendah.

\section{Asupan Lemak Tikus Selama Fase Perlakuan}

Hasil uji One Way ANOVA menunjukkan bahwa ada perbedaan asupan lemak yang signifikan pada kelima kelompok perlakuan dengan nilai $\mathrm{p}<0,001$ $(\alpha=0,05)$. Asupan lemak selama fase perlakuan dapat dilihat pada gambar 3 . 


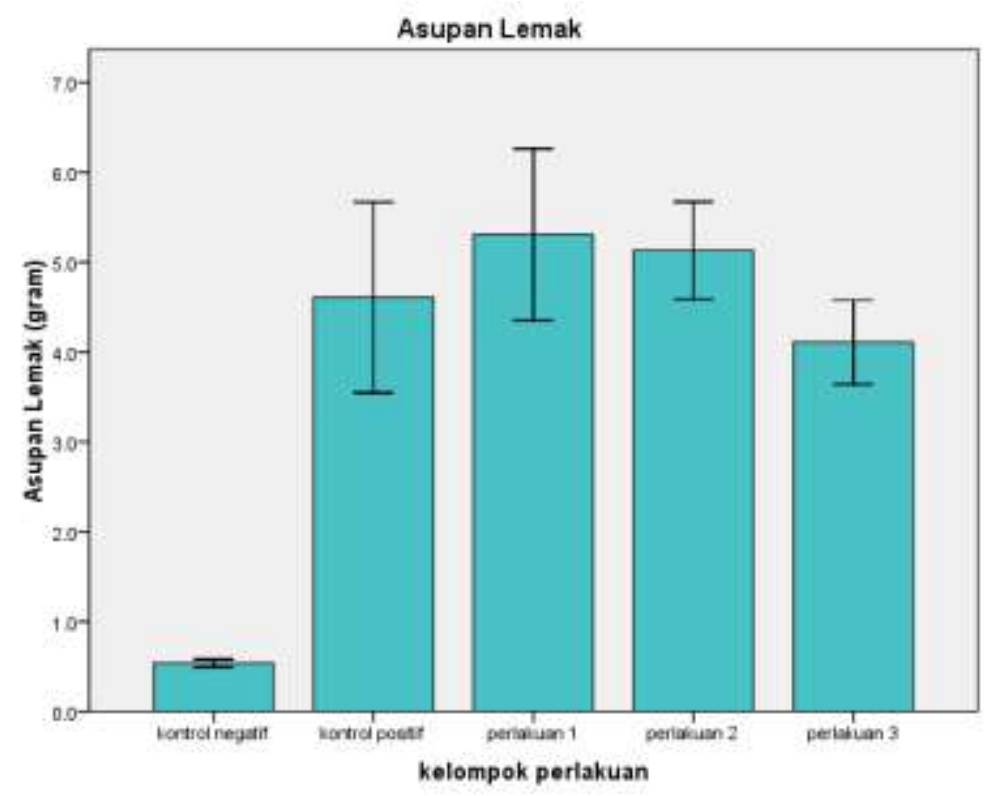

Gambar 3. Asupan lemak tikus per hari selama fase perlakuan.

Asupan lemak pada kelompok $\mathrm{K}(-)$ berbeda signifikan terhadap kelompok $\mathrm{K}(+)$, P1, P2, dan P3. Asupan lemak pada kelompok P3 juga berbeda signifikan terhadap kelompok P1. Diet aterogenik mempunyai kadar lemak yang tinggi sehingga dalam berat ransum yang sama mampu menghasilkan energi yang jauh lebih banyak daripada diet normal. Pada diet aterogenik, sekitar 46,9\% total energi berasal dari lemak sedangkan pada diet standar hanya 7,97\%. Oleh sebab itulah walaupun tingkat asupan ransum pada kelompok $\mathrm{K}(-)$ paling tinggi, asupan lemaknya adalah yang paling rendah diantara kelompok lainnya. Kadar lemak yang tinggi pada diet aterogenik ini disebabkan oleh penambahan kuning telur bebek sebanyak 5\%, lemak kambing 10\%, minyak kelapa 1\%, minyak babi $8,9 \%$, dan asam kolat $0,1 \%$.

\section{Asupan Karbohidrat Tikus Selama Fase Perlakuan}

Hasil uji One Way ANOVA menunjukkan bahwa ada perbedaan asupan karbohidrat yang signifikan pada kelima kelompok perlakuan dengan nilai $\mathrm{p}<$ $0,001(\alpha=0,05)$. Asupan karbohidrat selama fase perlakuan dapat dilihat pada gambar 4. 


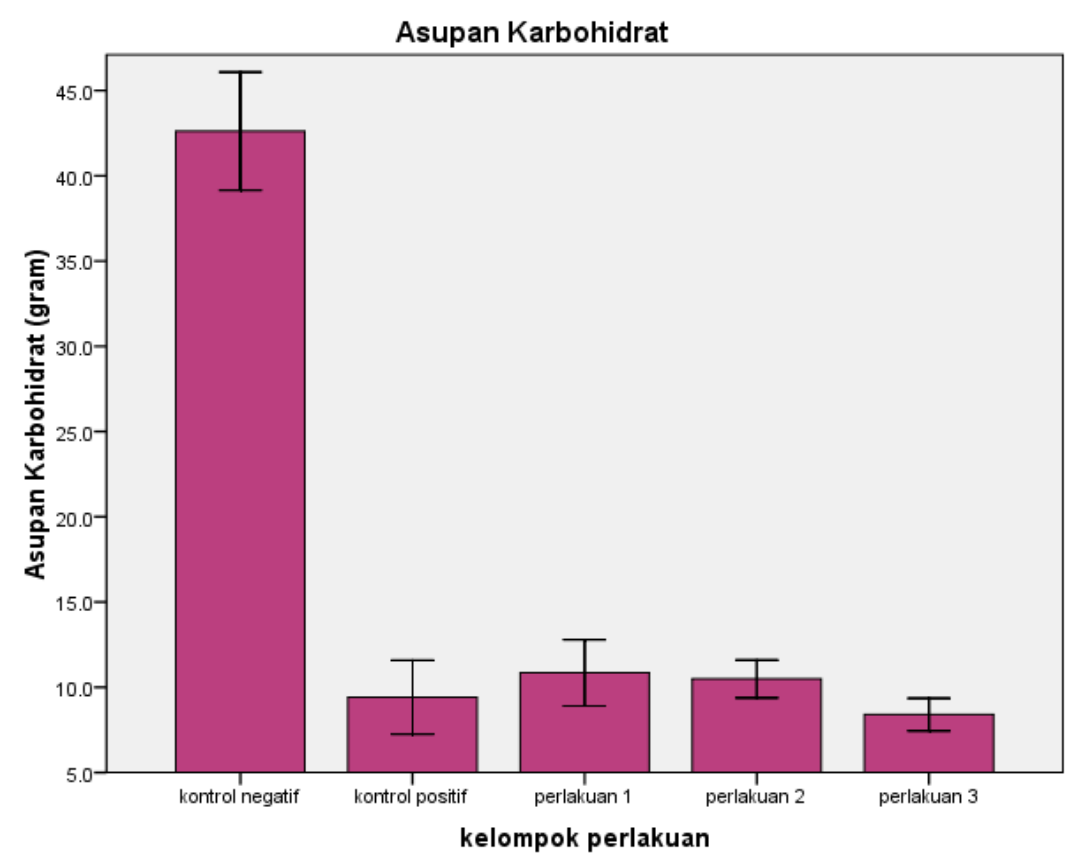

Gambar 4. Asupan karbohidrat tikus per hari selama fase perlakuan

Asupan karbohidrat pada kelompok $\mathrm{K}(-)$ berbeda signifikan terhadap kelompok K(+), P1, P2, dan P3. Diet normal mempunyai kadar karbohidrat yang lebih tinggi daripada diet aterogenik. Pada diet normal, sekitar $72,7 \%$ total energi berasal dari karbohidrat sedangkan pada diet aterogenik hanya 41,2\%. Hal ini menjadi alasan asupan karbohidrat pada kelompok $\mathrm{K}(-)$ berbeda signifikan terhadap kelompok $\mathrm{K}(+), \mathrm{P} 1, \mathrm{P} 2$, dan P3.

\section{Ketebalan Dinding Aorta Tikus}

Ketebalan dinding aorta tertinggi adalah pada kelompok $\mathrm{K}(+)$, yaitu sebesar $82,5 \pm 7,78$, sedangkan rata-rata ketebalan dinding aorta yang terendah adalah pada kelompok $\mathrm{K}(-)$, yaitu sebesar $63,87 \pm 5,03$. Hasil uji One Way ANOVA menunjukkan bahwa ada perbedaan ketebalan dinding aorta yang signifikan pada kelima kelompok perlakuan dengan nilai $p<0,001(\alpha=0,05)$. Ketebalan dinding aorta dapat dilihat pada gambar 5 . 


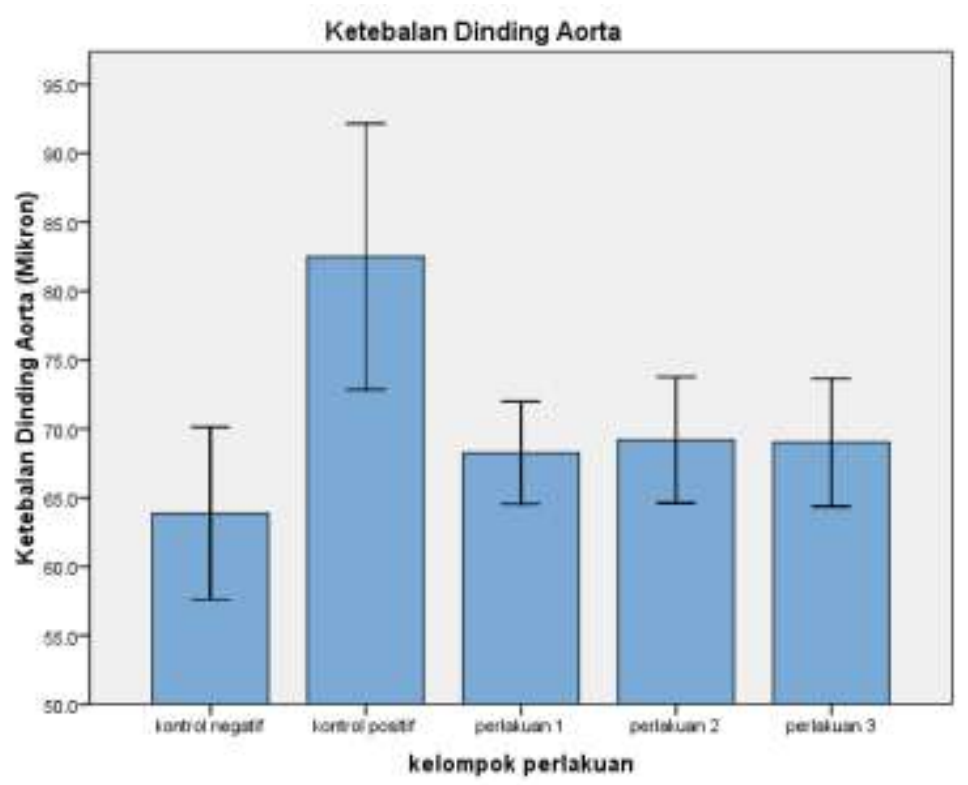

Gambar 5. Ketebalan Dinding Aorta Tikus

Ketebalan dinding aorta pada kelompok $\mathrm{K}(+)$ berbeda signifikan terhadap kelompok K(-), P1, P2 , dan P3. Selain itu, tidak ditemukan perbedaan ketebalan dinding aorta yang signifikan antara kelompok K(-), P1, P2, dan P3.

Ketebalan dinding aorta pada kelompok $\mathrm{K}(+)$ berbeda signifikan terhadap kelompok lainnya karena kelompok $\mathrm{K}(+)$ adalah kelompok yang diberi diet aterogenik selama 60 hari tanpa pemberian sari buah markisa ungu. Diet aterogenik mengandung lemak tinggi $(46,9 \%$ dari total energi) dengan kandungan lemak jenuh dan kolesterol tinggi yang berasal dari kuning telur bebek, lemak kambing, minyak babi dan asam kolat. Diet yang mengandung lemak jenuh dan kolesterol dapat menurunkan reseptor LDL dimana peningkatan kolesterol intrasel yang berasal dari lipoprotein darah menurunkan pembentukan kolesterol dalam sel, merangsang penyimpanan kolesterol sebagai ester kolesterol, akan memberikan tanda pada sel hati untuk menghambat transkripsi gen reseptor LDL, sehingga akan sedikit reseptor LDL yang disintesis akibatnya kadar kolesterol LDL dalam sirkulasi akan meningkat (Dawn, 2000).

Sebagian besar komponen lipid pada LDL adalah berupa asam lemak tak jenuh ganda (PUFA) yang sangat rentan terhadap oksidasi karena ikatan rangkapnya (Wibowo, 2003). Mekanisme oksidasi LDL diperantarai oleh enzimenzim NADPH oxidase, myeloperoxidase, cytochrome P450, peroxynitrite, xanthine oxidase, lipoxygenase, ROS yang dihasilkan oleh makrofag, sel otot polos, dan sel endotel di dalam lesi aterosklerosis (Anitra et al., 2000). Oksidasi LDL oleh enzim-enzim tersebut menyebabkan LDL mengalami proses peroksidasi lipid (Tsimikas et al., 2005). 
Peroksidasi lipid ini berawal dari modifikasi polyunsaturated fatty acids (PUFA), bagian dari fosfolipid LDL menjadi lipid hydroperoxide. Lipid hydroperoxide ini mengalami degradasi menjadi fragmen-fragmen seperti malondialdehyde (MDA) dan phosphorylcholine (PC) (Tsimikas et al., 2005). Fragmen tersebut akan menstimulasi sel endotel untuk mensekresikan beberapa molekul yaitu, Vascular Cell Adhesion Molecule-1 (VCAM-1), Intercellular Adhesion Molecule-1 (ICAM-1), Monocyte Chemoattractant Protein-1 (MCP-1), Interleukin-8 (IL-8) pada permukaan endotel pembuluh darah. Molekul-molekul tersebut menyebabkan terjadinya adesi monosit pada endotel yang diikuti dengan kemotaksis ke dalam subendotel dan terjadi aktivasi serta diferensiasi makrofag (Frostegard et al., 2007). Penangkapan kembali LDL teroksidasi oleh makrofag melalui reseptor scavenger secara terus menerus akan menyebabkan kematian makrofag menjadi sel busa karena LDL teroksidasi bersifat sitotoksik, sehingga terjadi penumpukan lemak (fatty streak). Penumpukan lemak mengawali terbentuknya plak aterosklerosis. Plak yang terbentuk ini semakin lama semakin menumpuk dan menyebabkan penebalan pada dinding aorta (Suryohudoyo, 2000).

Penelitian ini menunjukkan adanya penurunan ketebalan dinding aorta yang signifikan $(\mathrm{p}<0,001)$ antara kelompok P1, P2, dan P3 dibanding kelompok $\mathrm{K}(+)$. Ketebalan dinding aorta antara kelompok P1 dan P2 tidak berbeda signifikan $(\mathrm{p}=0,998)$. Hal ini disebabkan rata-rata tingkat asupan pakan, asupan energi dan asupan lemak antar keduanya yang juga berbeda tidak signifikan $(\mathrm{p}>0,05)$. Ketebalan dinding aorta kelompok P1 yang lebih rendah daripada kelompok P2 membuktikan bahwa peningkatan dosis konsumsi sari buah markisa ungu tidak membuat penurunan ketebalan dinding aorta yang lebih banyak pada tikus yang diberi diet aterogenik. Sementara itu, pada kelompok P3 juga memiliki ketebalan dinding aorta yang tidak berbeda signifikan dengan kelompok P1 $(p=0,999)$ dan P2 $(p=1,000)$. Akan tetapi dengan dosis pemberian tertinggi sari buah markisa ungu, ketebalan dinding aorta pada kelompok P3 lebih rendah daripada P2. Hal ini terjadi mungkin disebabkan karena kelompok P3 mengalami stres fisiologis yang lebih tinggi akibat mendapatkan 2 kali sonde sehingga tingkat asupan pakan, asupan energi maupun lemak lebih rendah dibanding kelompok P2. Dengan demikian mengakibatkan jumlah foam cell yang terbentuk lebih sedikit sehingga ketebalan dinding aorta pada kelompok P3 lebih rendah daripada kelompok P2.

Pemberian sari buah markisa ungu dengan dosis $17,5 \mathrm{ml} / \mathrm{kgBB}$ pada kelompok P1, yang merupakan dosis terkecil pemberian sari buah markisa ungu, sudah menunjukkan pengaruh yang signifikan terhadap penurunan ketebalan dinding aorta yang dibuktikan dengan nilai ketebalan yang berada dibawah nilai kontrol positif dan juga hasil uji Post Hoc Tukey yang menunjukkan perbedaan 
tidak signifikan terhadap kelompok kontrol negatif $(p=0,636)$ sehingga dosis ini merupakan dosis yang dapat direkomendasikan pada tikus dengan keadaan aterosklerosis. Hal ini menunjukkan bahwa sari buah markisa ungu (Passiflora edulis var. edulis Sims) dapat menurunkan ketebalan dinding aorta tikus (Rattus norvegicus strain Wistar) yang mengalami aterosklerosis melalui peran antioksidan sebagai pencegah terjadinya oksidasi LDL. Sari buah markisa ungu banyak mengandung, B-karoten, senyawa flavonoid, dan vitamin C yang mempunyai aktivitas antioksidan yang kuat.

Beta karoten sebagai scavenger menetralkan radikal bebas, terutama radikal lipid peroksil dengan cara mengikat oksigen sehingga reaksi oksidasi tidak terjadi (Syarkiah, 2008). B-karoten juga menghambat aktivitas enzim lipoxigenase, yaitu salah satu enzim yang dapat mengoksidasi LDL (Parwata et al., 2010). Penelitian yang dilakukan oleh Levy et al. (1996) dalam mengenai efek suplementasi B-karoten terhadap oksidasi LDL oleh makrofag, menyebutkan bahwa 6 -karoten dapat menurunkan oksidasi LDL yang dikatalis oleh tembaga sebesar 40 \% (Seo et al., 2004). Beta karoten juga berfungsi memperlambat berlangsungnya penumpukan plak pada arteri (Andi, 2005).

Vitamin C bersifat larut dalam air sehingga merupakan antioksidan utama dalam plasma terhadap serangan radikal bebas dan juga berperan dalam sel. Vitamin $\mathrm{C}$ dapat menjadi donor elektron untuk radikal bebas seperti hidroksil dan superoksida. Konsentrasi fisiologis vitamin $\mathrm{C}$ dapat menghambat modifikasi oksidatif dari LDL dengan cara membersihkan radikal peroksil pada fase cair sebelum menginisiasi peroksidasi lipid dan dengan regenerasi bentuk aktif vitamin E yang merupakan antioksidan yang larut dalam lemak (Wibowo, 2003).

Flavonoid dapat mencegah kerusakan oksidatif dan oksidasi LDL. Aktivitas antioksidan flavonoid dapat dilakukan melalui beberapa mekanisme, yaitu sebagai scavenger bagi radikal bebas oksigen dan nitrogen, pengikat ion-ion logam yang mampu mengkatalis reaksi oksidasi, dan penghambatan reaksi propagasi dalam peroksidasi lipid (Fuhrman \& Aviram, 2001; Mira et al, 2002). Selain itu aktivitas antioksidan dari flavonoid juga dapat terjadi melalui penghambatan oksigenase seluler dan peningkatan antioksidan seluler. Flavonoid juga memiliki efek anti inflamasi, menurunkan kolesterol, antihipertensi dan antiplatelet. Fitokimia ini menghambat proliferasi dan migrasi sel otot polos serta meningkatkan fungsi pembuluh darah (Gross, 2004).

Hasil penelitian ini menunjukkan bahwa pemberian sari buah markisa ungu dengan dosis standar (sesuai anjuran kebutuhan) dapat menurunkan ketebalan dinding aorta (Rattus norvegicus strain Wistar) yang disebabkan oleh peranan senyawa antioksidan (beta karoten, vitamin C, dan flavonoid) yang terdapat pada sari buah markisa ungu. 


\section{KESIMPULAN}

Kesimpulan yang diperoleh dari penelitian ini diantaranya pemberian sari buah markisa ungu (Passiflora edulis var. edulis Sims) mampu menurunkan ketebalan dinding aorta tikus (Rattus norvegicus strain wistar) yang dipapar diet aterogenik. Pemberian sari buah markisa ungu (Passiflora edulis var. edulis Sims) sebesar $17,5 \mathrm{ml} / \mathrm{kgBB} /$ hari selama 60 hari merupakan dosis efektif yang mampu menurunkan ketebalan dinding aorta tikus percobaan.

\section{REFERENSI}

American Heart Association. 2011. Cardiovascular Disease Statistics, (online) http://www.americanheart.org/presenter.jhtml.identifier $=4591$, diakses 4 Januari 2011).

Andi, N.A.S. 2005. Perpaduan Sang Penakluk Penyakit VCO + Buah Merah. PT. Agromedia Pustaka, Jakarta.

Anis. 2006. Waspada Ancaman Penyakit Tidak Menular, Solusi Pencegahan dari Aspek Perilaku \& Lingkungan. PT Elex Media Komputindo, Jakarta, hal. 53-65.

Anitra C, McCall, Frei B. 2000. Oxidation of LDL by Myeloperoxidase and Reactive Nitrogen Species: Reaction Pathways and Antioxidant Protection. American Heart Association, Vol. 20:1716-1723.

Anwar, T. B. 2004. Dislipidemia Sebagai Faktor Resiko Penyakit Jantung Koroner. E-USU Repository Universitas Sumatera Utara, hal.2.

Baedori, A.Z. 2008. Pengaruh Pemberian Jus Apel (Mallus sylvestris mill-Rome Beauty) terhadap Pembentukan Foam Cell di Lapisan Intima Dati Aorta Tikus Jantan Rattus norvegicus Strain Wistar yang Diberi Diet Aterogenik. Tugas Akhir tidak diterbitkan, Malang: Fakultas Kedokteran Universitas Brawijaya.

[BALITBANGKES] Badan Penelitian dan Pengembangan Kesehatan. 2013. Laporan Nasional Riset Kesehatan Dasar (RISKESDAS) 2013. Lembaga Penerbit Badan Penelitian dan Pengembangan Kesehatan, Jakarta.

Carr, Anitra C., Ben-Zhan Zhu, BalzFrei. 2000. Potential Antiatherogenic Mechanisms of Ascorbate (VitaminC) and a-Tocopherol (VitaminE). Circulation Research American Heart Association Inc, p. 349-351.

Dalimartha, S. 2008. Atlas Tumbuhan Obat Indonesia Jilid 5. Pustaka Bunda, Jakarta.

Dawn B.M, Allan DM, Collen MS. 2000. Biokimia Kedokteran Dasar sebuah Pendekatan Klinis. Penerbit Buku Kedokteran EGC, Jakarta.

Direktorat Kesehatan dan Gizi Masyarakat Kedeputian Sumber daya manusia dan Kebudayaan. Badan Perencanaan Pembangunan Nasional. 2009. Laporan Pengembangan Database Pembangunan Bidang Kesehatan dan Gizi Masyarakat, Jakarta. hal. 66.

Frostegard, et al. 2007. Atheroprotective natural anti-phosphorylcholine antibodies of IgM subclass are decreased in Swedish controls as compared to 
non-westernized individuals from New Guinea. Journal of Nutrition \& Metabolism,Vol. 4 No. 7

Fuhrman B, Aviram M. 2001. Flavonoids protect LDL from oxidation and attenuate atherosclerosis. Curr Opin Lipidol 12: 41.

Gross, M. 2004. Flavonoids and Cardiovascular Disease, Pharmaceutical Biology. Taylor \& Francis Group Vol.42, Supplement, p. 21-35.

Hakimah, I. A. 2010. 81 Macam Buah Berkhasiat Istimewa, Syura Media Utama, Bantul.

Hollopeter, G., Erickson, J.C., Seeley, R.J., Marsh, DJ. and Palmiter, R.D. 1998. Response of neuropeptide $Y$-deficient mice to feeding effectors. Regulatory Peptides 75-6: 383-389.

Karsinah, R.C. Hutabarat, A. Manshur. 2010. Markisa Asam (Passiflora Edulis Sims) Buah Eksotik Kaya Manfaat. Iptek Hortikultur. hal.30-35

Mira L, Fernandez MT, Santos M, Rocha R, Florencio MH, Jennings KR. 2002. Interactions of flavonoids with iron and copper ions: A mechanism for their anti-oxidant activity. Free Radic Res 36: 1199.

Muchtadi, D. F. 2007.ormulasi Produk Pangan Pencegah Penyakit Jantung Koroner. Food Review Vol II No.3 Maret hal: 26.

Parwata, I M. Oka Adi, K. Ratnayani, dan Ana L. 2010. Aktivitas Antiradikal Bebas serta Kadar Beta Karoten pada Madu Randu (Ceiba pentandra) dan Madu Kelengkeng (Nephelium longata L.), Jurnal Kimia 4 (1): 54-62 Jurusan Kimia FMIPA Universitas Udayana, Bukit Jimbaran.

[PERKI] Persatuan Dokter Spesialis Kardiovaskular Indonesia. 2019. Hari Jantung Sedunia (World Heart Day): Your Heart is Our Heart Too. http://www.inaheart.org/news_and_events/news/2019/9/26/press_release_wo rld_heart_day_perki_2019, diakses 10 Januari 2020.

P2PTM Kemenkes RI. 2019. Hari Jantung Sedunia (HJS) Tahun 2019 : Jantung Sehat, SDM Unggul. http://p2ptm.kemkes.go.id/kegiatan-p2ptm/pusat-/harijantung-sedunia-hjs-tahun-2019-jantung-sehat-sdm-unggul, diakses 10 Januari 2020.

Sandjaja, et al. 2009. Kamus Gizi. Penerbit Buku Kompas, Jakarta.

Seo, Jung Sook, Kyeung Soon Lee, Jung Hyun Janga, Zhejiu Quana, Kyung Mi Yang, Betty Jane Burri. 2004. The effect of dietary supplementation of $b^{-}$ carotene on lipid metabolism in streptozotocin-induced diabetic rats. Nutrition Research 24 1011-1021.

Suryohudoyo P. 2000. Kapita Selekta Ilmu Kedokteran Molekuler. Jakarta: CV Sagung Seto.

Susiana C, Lantip R \& Thianti S. 2006. Kadar Malondiadehid (MDA) Penderita Penyakit Jantung Koroner di RSUP Dr. Sardjito Yogyakarta. Mandala of Health, a Scientific Journal, Vol $2: 47-54$.

Syarkiah, Loeki Enggar Fitri. 2008. Astutik Pudjirahayu. Pengaruh Pemberian Minyak Buah Merah (Pandanus conoideus oil) Terhadap Foam Cell Pada Aorta Tikus Galur Wistar (Rattus norvegicus) Dengan Diet Aterogenik. Jurnal Kedokteran Brawijaya Vol. XXIV No.1

Triyanto, B. J. 2009. Hubungan Antara Asupan Lemak dan Asupan Kolesterol dengan Status Gizi Pada penderita jantung Koroner di Poliklinik Jantung 
RSUD dr. Moewardi Surakarta. Tugas Akhir. Program Studi Diploma III Gizi Fakultas Ilmu Kesehatan Universitas Muhammadiyah Surakarta.

Tsimikas, et al.. 2005. Oxidized Phospholipid, Lp(a) Lipoprotein, And Coronary Artery Disease. New England Journal of Medicine Vol. 353:46-57.

Whiting, K.Steven. 2004. How Antioxidants and Free Radical Scavenging Nutrients Can Prevent Disease and Extend Your Life. Report No.12. (www.HealthyInformation.com, diakses 1 Juli 2011)

Wibowo, Joko Wahyu. 2003. Pengaruh Pemberian Suplementasi Vitamin E dan Vitamin C terhadap Profil Lipid dan Ketebalan Dinding Aorta Abdominalis Tikus yang Mendapat Diet Tinggi Kolesterol. Tesis. Tidak Diterbitkan, Program Pasca Sarjana Magister Ilmu Biomedik Universitas Diponegoro, Semarang.

Winarno, F.G. 2002. Kimia Pangan dan Gizi. Jakarta: PT. Gramedia Pustaka Utama. 